\title{
A (relatively) risky business: the link between prostatic radiotherapy and second malignancies
}

\author{
(9) (1) (8) OPEN ACCESS \\ Unlikely to change therapeutic decisions for most men with high grade prostate cancer
}

Christine E Eyler clinical fellow ${ }^{1}$, Anthony L Zietman professor of radiation oncology ${ }^{2}$

${ }^{1}$ Harvard Radiation Oncology Program, Boston, MA, USA; ${ }^{2}$ Massachusetts General Hospital, Boston MA 02114, USA

There is a well recognized association between exposure to radiation and carcinogenesis. ${ }^{1}$ The development of second malignancies after therapeutic radiation depends on the primary malignancy, the dose to tissues at risk, and specific characteristics of the patient. ${ }^{2}$ There is a strong association between radiotherapy and second malignancies in people with Hodgkin's lymphoma ${ }^{34}$ and patients with other cancers treated with radiotherapy. ${ }^{5}$ Data linking radiotherapy for prostate cancer and subsequent malignancy have been less clear. Defining such a link has been difficult because the population is older and has a limited natural lifespan with prominent competing health risks. In addition, the relatively small number of outcomes in these analyses limits their statistical validity. Previous systematic reviews and one small meta-analysis reported inconsistent conclusions. ${ }^{7-9}$

In a linked paper, Wallis and colleagues (doi:10.1136/bmj.i851) ${ }^{10}$ refresh the existing data with an updated comprehensive systematic review and meta-analysis of 21 studies evaluating the association between prostatic irradiation and likelihood of a second malignancy. Their analysis suggests an increased risk of bladder (odds ratio 1.39), rectal (1.62), and colorectal (1.68) cancers. A subgroup analysis of patients treated with radiotherapy compared with those treated surgically confirmed this risk. This analysis deals with a limitation of previous studies that used the general public as a control group, despite the known diagnostic bias toward identification of cancer in men with prostate cancer. ${ }^{11}$

Previous studies have adopted variable "lag times" (ranging from two months to over 10 years) to define a tumor as "radiation induced." The latency of such tumors likely varies by tissue type, individual biology, and age at exposure, among other factors. ${ }^{12-14}$ Importantly, in the absence of a clear biologically justified "lag time" for analysis, Wallis and colleagues confirmed that risk estimates after adjustment for "lag times" of both five or 10 years were consistent with their pooled risk estimates. ${ }^{10}$
From the perspective of the radiation oncologist, this study "firms up" the suspicion that irradiation of the prostate increases the risk of second bladder and colorectal cancers in a time dependent manner. A pragmatist, however, might ask, what are the real world implications for individual patients? Despite an impressive relative risk, the absolute risk remains small, and the cancers discovered, although certainly requiring treatment, might not be lethal. This is particularly true of smaller bladder cancers discovered incidentally during cystoscopy for radiation related hematuria, which is a relatively common event. Indeed, there seems to be no survival difference between men with bladder cancers linked to previous prostate irradiation and bladder cancers identified in patients treated with surgery. ${ }^{15}$ Ultimately, clinicians and patients must decide together whether, for example, the roughly 1.4-1.7-fold increase in relative risk of a second malignancy after a 10 year lag period justifies alternative treatments. Young patients with few comorbidities might be more likely to factor this risk into their decision making, whereas older patients or those with competing health risks, might not and indeed should not.

Wallis and colleagues found a notable effect of "tissue volume," and brachytherapy (high radiation dose to a small volume of tissue) was not associated with a detectable increase in risk. Therefore, the current move towards smaller tighter treatment volumes might well shift the contemporary risk back towards unity. Many studies included in this analysis were performed at a time when older poorly targeted radiation techniques were used, and large volumes of normal pelvic tissue were irradiated during treatment

While the absolute risk of second malignancy seems small, there might be subgroups with higher absolute risks and others for whom risks are negligible. Prospective analyses with large multi-institutional databases and registries could identify the predisposing characteristics of patients and culpable technical factors associated with radiation associated malignancies.

Combination of these analyses with paired biologic samples of tumor and normal tissue might additionally permit investigation 
of subtle genetic or epigenetic factors that influence the likelihood of tumors associated with radiation.

For now, we note the risk of second malignancy after prostate irradiation confirmed by Wallis and colleagues and believe that management discussions and consent forms should feature this information. This analysis further supports the move towards even more tightly targeted external radiation techniques. Perhaps most important, this study confirms our belief that second malignancy should be added to the already long list of avoidable hazards associated with treatment for those men with low risk prostate cancer who simply need no treatment at all. Concern about second malignancies should not, however, stand in the way of an effective and well studied treatment being given to men with higher grade, lethal prostate cancer for whom the potential benefit simply dwarfs the risk.

Competing interests: We have read and understood the BMJ Group policy on declaration of interests and declare the following interests: none.

Provenance and peer review: Commissioned; not externally peer reviewed.

1 Preston DL, Shimizu Y, Pierce DA, Suyama A, Mabuchi K. Studies of mortality of atomic bomb survivors. Report 13: Solid cancer and noncancer disease mortality: 1950-1997. Radiat Res 2003:160:381-407 doi:10.1667/RR3049, 12968934

2 Berrington de Gonzalez A, Curtis RE, Kry SF, et al. Proportion of second cancers attributable to radiotherapy treatment in adults: a cohort study in the US SEER cancer registries. Lancet Oncol 2011;12:353-60. doi:10.1016/S1470-2045(11)70061-4. 21454129.

3 Moskowitz CS, Chou JF, Wolden SL, et al. Breast cancer after chest radiation therapy for childhood cancer. J Clin Oncol 2014;32:2217-23. doi:10.1200/JCO.2013.54. 4601. 24752044

4 Bhatia S, Robison LL, Oberlin O, et al. Breast cancer and other second neoplasms after childhood Hodgkin's disease. N Engl J Med 1996;334:745-51. doi:10.1056 NEJM199603213341201. 8592547.
5 Travis LB, Fosså SD, Schonfeld SJ, et al. Second cancers among 40,576 testicular cancer patients: focus on long-term survivors. J Nat/ Cancer Inst 2005·97:1354-65. doi:10.1093/ inci/dji278. 16174857.

6 Berrington de Gonzalez A, Curtis RE, Gilbert E, et al. Second solid cancers after radiotherapy for breast cancer in SEER cancer registries. Br J Cancer 2010;102:220-6. doi:10.1038/sj.bjc.6605435. 19935795.

7 Zelefsky MJ, Pei X, Teslova T, et al. Secondary cancers after intensity-modulated radiotherapy, brachytherapy and radical prostatectomy for the treatment of prostate cancer: incidence and cause-specific survival outcomes according to the initial treatment intervention. BJU Int 2012;110:1696-701. doi:10.1111/j.1464-410X.2012.11385 x. 22889401.

8 Murray L, Henry A, Hoskin P, Siebert FA, Venselaar J. PROBATE group of GEC ESTRO Second primary cancers after radiation for prostate cancer: a systematic review of the clinical data and impact of treatment technique. Radiother Oncol 2014;110:213-28. doi: 10.1016/j.radonc.2013.12.012. 24485765.

9 Jin T, Song T, Deng S, Wang K. Radiation-induced secondary malignancy in prostate cancer: a systematic review and meta-analysis. Urol Int 2014;93:279-88. doi:10.1159/ 000356115.25139441.

10 Wallis C, Mahar AL, Choo R, et al. Secondary malignancies after radiotherapy for prostate cancer: systematic review and meta-analysis. BMJ 2016;351:i851. doi:10.1136/bmj.i851.

11 Davis EJ, Beebe-Dimmer JL, Yee CL, Cooney KA. Risk of second primary tumors in men diagnosed with prostate cancer: a population-based cohort study. Cancer 2014;120:2735-41. doi:10.1002/cncr.28769. 24842808.

12 Cardis E, Vrijheid M, Blettner M, et al. The 15-Country Collaborative Study of Cancer Risk among Radiation Workers in the Nuclear Industry: estimates of radiation-related cancer risks. Radiat Res 2007;167:396-416. doi:10.1667/RR0553.1. 17388693

13 Richardson DB, Sugiyama $\mathrm{H}$, Wing S, et al. Positive associations between ionizing radiation and lymphoma mortality among men. Am J Epidemiol 2009;169:969-76. doi:10.1093/aje/ kwp018. 19270049

14 Preston DL, Kusumi S, Tomonaga M, et al. Cancer incidence in atomic bomb survivors. Part III. Leukemia, lymphoma and multiple myeloma, 1950-1987. Radiat Res 1994:137(Suppl):S68-97. doi:10.2307/3578893. 8127953.

15 Sandhu JS, Vickers AJ, Bochner B, Donat SM, Herr HW, Dalbagni G. Clinical characteristics of bladder cancer in patients previously treated with radiation for prostate cancer. BJU Int 2006;98:59-62. doi:10.1111/j.1464-410X.2006.06182.x. 16626308.

Published by the BMJ Publishing Group Limited. For permission to use (where not already granted under a licence) please go to http://group.bmj.com/group/rights-licensing/ permissions

This is an Open Access article distributed in accordance with the Creative Commons Attribution Non Commercial (CC BY-NC 3.0) license, which permits others to distribute, remix, adapt, build upon this work non-commercially, and license their derivative works on different terms, provided the original work is properly cited and the use is non-commercial. See: http://creativecommons.org/licenses/by-nc/3.0/. 